\title{
Benthic molluscan macrofauna structure in heavily trawled sediments (Thermaikos Gulf, North Aegean Sea): spatiotemporal patterns
}

\author{
Charalampos Dimitriadis ${ }^{1,3^{*}}$, Drosos Koutsoubas ${ }^{1,3}$, Zoi Garyfalou ${ }^{1}$ and Anastasios Tselepides ${ }^{2}$
}

\begin{abstract}
Background: Spatio-temporal patterns on benthic molluscan macrofauna structure and function (feeding guilds) were investigated in a commercial fishing ground in Thermaikos Gulf (N Aegean Sea). Fishery management measures in this area include a trawling period of 8 months per year (October to May). Macrofauna samples were collected before and after 30 and 120 days of the commencement of the trawling period (temporal axis) along a southward transect (spatial axis) and down through the sediment profile (vertical axis).

Results: Main results revealed no recognizable changes in community diversity and structure at temporal scales. This finding can probably be attributed to the fact that the examined communities are subjected to continuous disturbances deriving from multiple natural and anthropogenic stressors acting simultaneously in Thermaikos Gulf. Molluscan assemblages were already stressed before the commencement of the trawling period, indicating that the time period in which bottom trawling is prohibited is not sufficient for the recovery of benthic communities. Significant shifts in the trophic structure of molluscan assemblages were also detected. The direct mortality of herbivorous species and the loss of filter feeding organisms may be attributed to the passage of the fishing gear and to sediment re-suspension, respectively. Trawling disturbance may have created the observed vertical patterns of the community structure since hauling induces profound changes in the geochemical profile of the sediment.

Conclusions: Our findings sustained the notion that bottom trawling, alongside with other types of human induced stressors, can have considerable effects on the structure and function of the benthic domain. Therefore, our results highlighted the need of an Ecosystem Based Fishery Management (EBFM) perspective in Thermaikos Gulf to ensure both fisheries and ecosystem sustainability.
\end{abstract}

Keywords: Bottom trawling, Sediment profile, Thermaikos gulf, Macrofauna

\section{Background}

In the last decades, there has been growing evidence of the wide effects of bottom trawling on marine ecosystems [1-4]. Nowadays, it is well known that physical disturbance caused by bottom trawling can be classified as one of the most important sources of human induced disturbance to soft-sediment benthic communities and habitats [5-7]. Both experimental and field studies have shown that bottom trawling modifies seabed morphology and complexity,

\footnotetext{
* Correspondence: xdimitriadis@marine.aegean.gr

'Department of Marine Sciences, Faculty of Environment, University of the Aegean, 81000 Mytilene Lesvos Island, Greece

${ }^{3}$ National Marine Park of Zakynthos, El. Venizelou 1, 29100 Zakynthos Island, Greece

Full list of author information is available at the end of the article
}

changes the community structure of the resident biota and affects benthic production and functionality [1,6,8-10]. These alterations of the benthic ecosystem could in return induce secondary impacts on many commercially exploited fish species affecting total production [4].

Macrofauna is frequently used to detect bottom trawling disturbance because it is relatively easy to sample and process, is directly affected by the passage of the fishing gear as species are directly killed or damaged, and it also provides information about habitat structure [2]. In this respect, bottom trawling effects are known to be harsher for species with hard shells, larger body sizes and slow life histories rather than for flexible species with smaller body sizes $([6,11,12]$ but also see [13]). Therefore, it is reasonable to expect that larger bivalves will suffer higher 
mortality rates from trawling while smaller bivalves, gastropods and polychaetes will present lower mortality since lighter organisms are pushed aside by the pressure wave in front of the fishing gear [14]. As a result, in intensively trawled sediments small infaunal species are expected to proliferate, since they usually exhibit higher resilience after disturbance events, whereas larger epifaunal organisms are expected to be absent [14,15].

While many field studies on benthic fauna response to bottom trawling have been conducted in northern European, little is known for Eastern Mediterranean waters $[16,17]$ despite the fact that it is characterized by unique attributes [18,19], rich benthic biota [20], intense fishing pressure and overfished stocks [21,22]. Thermaikos Gulf (N. Aegean Sea, Eastern Mediterranean) is characterized by increased productivity, and by an extended self (180 km long $\times 55 \mathrm{~km}$ wide) with smooth bathymetry, which is mainly comprised of soft sediments [23 and references therein]. In this respect, it is an ideal area for bottom trawling, constituting one of the most important fishing grounds in Greek waters [24]. According to Greek law (Presidential Decree 189/1978) the trawling season spans from October to the end of May (8 months per year), whereas trawling activity is permanently banned in the inner part of Thermaikos Gulf (Thessaloniki Bay) in an effort to protect the fish stocks.

The present study aims to address the structure and function (feeding guilds) of macrobenthic molluscan assemblages in a heavily trawled fishing ground of the Eastern Mediterranean, Thermaikos Gulf (N Aegean Sea), along spatiotemporal axes, down through the sediment profiles.

\section{Results and discussion}

\section{Spatial and temporal patterns in molluscan diversity}

A total of 4410 organisms belonging to 74 Molluscan species were recorded in the study area. Gastropoda was the most dominant class, in terms of species number (64\%), followed by Bivalvia (32\%), Scaphopoda (2\%) and Aplacophora (2\%). Considering their zoogeographic affinity, most of the collected species were of AtlantoMediterranean origin (60\%), whereas Boreal and Endemic species presented much lower numbers (26\% and $14 \%$, respectively). Infaunal organisms dominate constituting $70 \%$ of the collected species. In terms of numerical dominance, the bivalve Corbula gibba accounted for $26.7 \%$ of the total abundance, whereas the gastropod Turritella communis and the bivalves Kurtiella bidentata and Thyasira biplicata accounted for $13.6 \%, 13.1 \%$ and $7.7 \%$ of total abundance, respectively.

Predators (27\%) were the dominant feeding guild, in terms of species number (Figure 1), followed by parasites (23\%), suspension (20\%) and deposit feeders (16\%). The rest of the feeding guilds (herbivores and detritus

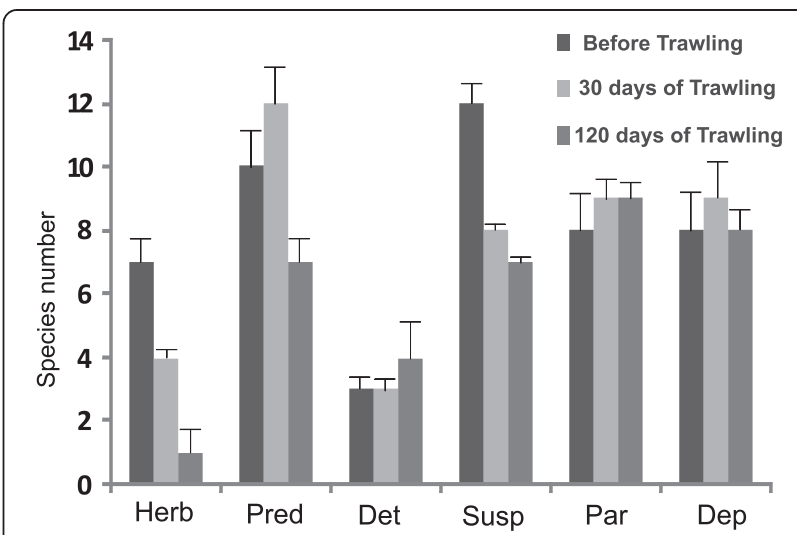

Figure 1 Feeding guilds' average species number. Average of species number of each feeding guild before ( $\mathbf{a})$ and after 30 ( $\mathbb{}$ ) and 120 days (iil) of trawling activity (Herb = Herbivores, Pred $=$ predators, Det $=$ detritus feeders, Susp $=$ suspension feeders, Par $=$ parasites, Dep $=$ deposit feeders) (Error bars represent standard error of average).

feeders) accounted for the remaining 14\%. Though the spatial variation of the allocation of species into feeding guilds within each sampling period was not significant (Man-Whitney test results, $p>0.05$ in all cases). Herbivores' diversity significantly decreased (Mann-Whitney test results, $p<0.05)$ at both after-trawling periods. A similar pattern was recorded for suspension feeders (Mann-Whitney test results, $p<0.05$ ), whereas, significantly lower number of predatory species was detected only during the second after-trawling period.

Hierarchical ANOVA model (two-way design) results regarding the observed spatial and temporal patterns of molluscan fauna descriptors' variation are presented in Table 1 . Our findings primarily suggested that temporal variation (between different sampling periods) of descriptors' values was not significant ( $p>0.05$ in all cases). However, spatial variability seemed to significantly account for the observed differences of abundance and diversity indices values. Pair-wise comparisons revealed that abundance values in station IP-38 were significantly higher in comparison to the rest of the sampling stations during September sampling period as well to the ones measured at station IP-10 during October sampling period $(p<0.05)$. When N1 index was examined, station IP-38 presented significantly higher values than the ones recorded in station IP-10 during all sampling periods ( $p<0.05$ in all cases). Evenness of the molluscan fauna (N21 index) varied considerably along the sampling transect since all the pair-wise comparisons between the sampling stations within each sampling period revealed statistically significant differences ( $p<0.05$ in all cases).

\section{Molluscan community structure}

Multivariate analyses (Figure 2 \& Table 2) did not reveal any consistent pattern in community structure with respect 
Table 1 Summary of results of two-way ANOVA considering biological descriptors values

\begin{tabular}{|c|c|c|c|c|}
\hline Source of variation & Species number (S) & Abundance $(\mathrm{N})$ & N1 & N21 \\
\hline \multirow[t]{4}{*}{ Sampling period } & $\mathrm{df}=2$ & $\mathrm{df}=2$ & $d f=2$ & $d f=2$ \\
\hline & $M S=0.015$ & $M S=0.444$ & $M S=0.035$ & $M S=0.002$ \\
\hline & $F=1.447$ & $F=2.244$ & $F=0.860$ & $F=1.876$ \\
\hline & $p=0.307$ & $p=0.187$ & $p=0.469$ & $p=0.233$ \\
\hline \multirow[t]{4}{*}{ Station (Sampling period) } & $d f=6$ & $d f=6$ & $d f=6$ & $d f=6$ \\
\hline & $M S=0.010$ & $M S=0.198$ & $M S=0.041$ & $M S=0.001$ \\
\hline & $F=0.681$ & $F=5.891$ & $F=2.814$ & $F=3.143$ \\
\hline & $p=0.667$ & $p=0.002^{*}$ & $p=0.041^{*}$ & $p=0.027^{*}$ \\
\hline
\end{tabular}

Summary of results of two-way ANOVA considering species number (S), species abundance (N) and Hill's diversity indices (N1 and N21) for factors sampling period (temporal effect-three levels: prior to trawling period, 30 and 120 days after intense bottom trawling period) and station (spatial effect-three levels: station IP-10, IP-17 and IP-38) (asterisk denotes statistically significant results).

to the different sampling periods (temporal effect) and therefore there were no recognizable changes in community structure before and after 30 and 120 days the initiation of the trawling period. Conversely, spatial variation seemed to significantly account for the observed differences in community structure (PERMANOVA results, Table 2). Pair-wise a posteriori comparisons revealed significant modifications of community structure between all the sampling stations during October as well as between stations IP-10 and IP-38 during February $(p<0.05)$.

\section{Molluscan diversity across sediment profiles}

Hierarchical ANOVA results (three-way design) with respect to the spatial and temporal variation of biological descriptors values (species number, abundance, diversity indices) along the sediment profiles are presented in Table 3. All the examined descriptors presented a common pattern of variation down through the sediment profiles. This pattern initially consisted of a steep decline in descriptors values at the transition from the surface sediment (0-5 cm depth) to the subjacent sediment layer $(5-10 \mathrm{~cm})$ (pair-wise comparisons, $p<0.05$ in all cases). The initial steep decline was subsequently followed by a milder but still significant further decline of descriptors values deeper in the sediment (10-20 cm) (pair-wise comparisons $p<0.05$ in all cases). Spatial variation component didn't contribute significantly to the observed variability of descriptors values along sediment profiles. Temporal variance component (between sampling periods) seemed to account for the observed differences in abundance and N21 index variation for the following cases: a) between October and February sampling periods when N21 index is considered and b) between October and February as well as between September and February sampling periods when abundance is considered.

\section{Macrofauna structure along sediment profiles}

Results of MDS ordination and Cluster analysis (Figure 3) demonstrated that molluscan community structure at the top $5 \mathrm{~cm}$ of the sediment was clearly distinguishable from the one observed deeper in the sediment. Similarly, the latter analyses also suggested the presence of different community structure of molluscan fauna between sediment layers of $5-10 \mathrm{~cm}$ and $10-20 \mathrm{~cm}$. PERMANOVA results considering the spatial and temporal effect in community structure down though the different sediment layers are presented in Table 4. Significant changes of community structure were detected between the different sediment layers whereas Pair-wise a posteriori comparisons suggested that the observed differences in community structure were mainly attributed to the comparison of the successive sediment layers $(0-5$ vs $5-10,5-10$ vs $10-20 \mathrm{~cm}$ ) down through the sediment profile $(p<0.05$ in all cases). Spatial variation seemed to significantly account for the observed differences in the vertical community structure along the sediment mainly as a result of the comparison between station IP-38 with the rest of the sampling stations (a posteriori pair-wise comparison; $p<0.05)$. An also apparent effect of the temporal variation in community structure down through the sediment profile was detected mainly as a result of the comparison between October and February sampling periods (a posteriori pair-wise comparison; $p<0.05$ ).

\section{Diversity and community structure}

Several authors have reported that the effects of trawling on benthic fauna diversity measures may be contradictory and as such they include decreases and increases in mean abundance of individual species, total abundance, species number and changes in various other metrics of diversity $[6,7]$. Our results suggested that molluscan diversity (abundance, species number and diversity indices) was mostly affected at spatial (between sampling stations) rather than temporal (between sampling periods) scale. This finding conformed to the previously described north-south productivity gradient [17], and also suggests that the multiple natural and anthropogenic stressors [25] are acting simultaneously and in concert in Thermaikos 


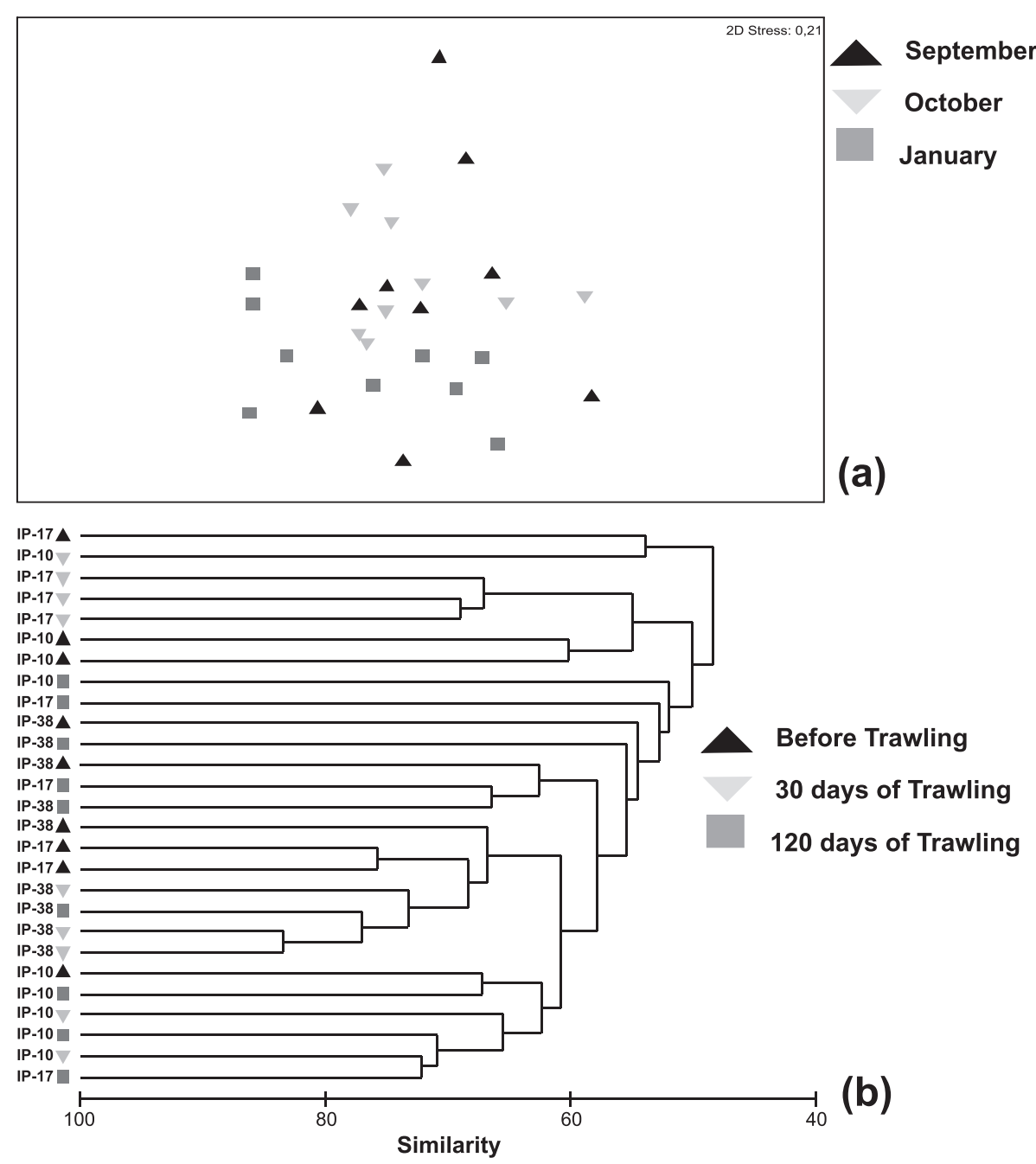

Figure 2 Multivariate patterns of community structure. (a) MDS ordination plot and (b) Cluster analysis of the sampling stations before the opening of the trawling season (September) as well as 30 (October) and 120 days (January) after.

Gulf. In this sense, given the increased dominance (in most sampling stations and periods) of Corbula gibba, Turritella communis, Thyasira biplicata and Kurtiella bidentata, which constitute species tolerant to organic matter enrichment and indicators of community instability [26,27], it is reasonable to conclude that benthic communities experience continual disturbance effects.

Multivariate analysis also revealed a shift in spatial community structure within all sampling periods towards the innermost areas of Thermaikos Gulf, rather than a seasonal community shift. Therefore, our data indicated that there was no clear evidence of trawling effects on benthic community structure in Thermaikos Gulf. Similarly, Lampadariou et al. [17] did not find any pronounced effect of bottom trawling on the seasonal structure of the nematode community in Thermaikos Gulf. It is well known that Thermaikos Gulf constitutes an area subjected for decades to heavy urbanization, industrialization and resource exploitation, whereas discharges by three major rivers (Axios, Aliakmon and Pinios) and intense fishing activity are inducing significant pressures to its biota [24,25]. Therefore, it seems that macrobenthic fauna is already adapted to the established disturbance regime and direct trawling effects are less visible $[11,14]$. Finally, the time period in which bottom trawling is prohibited (from May to October) is probably not sufficient for the recovery of benthic communities in the study area. Several authors have pointed out that benthic communities' recovery from bottom trawling impacts depends on the type of the habitat and its duration can vary from a few days up to many years $[3,7,28]$.

\section{Feeding guilds}

Predatory species were dominant in the study area. This finding seems to be in line with other studies reporting 
Table 2 Two-way PERMONAVA results regarding community structure

\begin{tabular}{|c|c|c|c|c|c|}
\hline Source of variation & df & SS & MS & Pseudo-F & $p$ \\
\hline Sampling period & 2 & 3792.8813 & 1896.44061 & 1.0132 & 0.5024 \\
\hline Station (Sampling period) & 6 & 11230.8464 & 1871.8077 & 1.9420 & $0.0001^{*}$ \\
\hline Residual & 18 & 37962.2111 & 790.8794 & & \\
\hline Total & 26 & 191573.6451 & & & \\
\hline
\end{tabular}

Summary of results of two-way PERMONAVA with respect to the temporal (three levels: prior to trawling period, 30 and 120 days after intense bottom trawling period) and spatial (three levels: station IP-10, IP-17 and IP-38) variation components of benthic community structure (asterisk denotes statistically significant results).

increased dominance of predatory macro- and meiofaunal species in heavily trawled areas or areas subjected to natural disturbance $[9,29,30]$. This can be attributed to the fact that predatory species probably gather in the tracks made by a trawl pass to feed on exposed and damaged or dead organisms [9,11,31]. Our results also suggested a significant decrease in the number of herbivore and suspension feeder species, after 30 and 120 days of intense trawling activity. It is broadly recognized that spatiotemporal variation of food availability is a major factor governing benthic communities' structure [32]. However, chlorophyll-a concentrations did not vary notably before and after the commencement of trawling in the study area and therefore microphytobenthic biomass was comparable between the sampling periods $[17,33]$. Thus, herbivores species reduction during October and January cannot be attributed to food limitation. On the contrary, several authors have stressed that epifaunal organisms are much more vulnerable in areas subjected to intense trawl fishing [2,12]. In this sense, given that most of the herbivores were epibenthic species (i.e. Alvania cimex, A. cimicoides, A. punctura, A. beanii, Rissoina bruguieri,
Circulus striatus), trawling disturbance in Thermaikos Gulf can possibly account for the reduction of macrobenthic herbivores.

It is well known that the passage of the fishing gear may induce re-suspension of a large amount of the sediment $[3,34]$. Indeed, an enhanced re-suspension process was mainly induced by bottom trawling during our sampling periods [23]. In this respect, re-suspension of the silty sediment in the study area [17] may obstruct the ciliary feeding mechanisms of the suspension feeding bivalves [35]. Thus, this process could explain the reduced number of suspension feeders, observed after 30 and 120 days of trawling activity. The above hypothesis was also sustained by the findings of Kaiser et al. [7] who, after the meta-analysis of 55 publications, detected a significant negative impact of bottom trawling on suspension feeding organisms in muddy habitats. Pusceddu et al. [33] have also concluded that bottom trawling might have important trophodynamic consequences for benthic microbial and meiofaunal assemblages in Thermaikos Gulf. Hence our study further suggests that bottom trawling, alongside with other human induced stressors, can have a significant footprint in the

Table 3 Three-way ANOVA results considering biological descriptors values

\begin{tabular}{|c|c|c|c|c|}
\hline Source of variation & Species number (S) & Abundance (N) & N1 & N21 \\
\hline \multirow[t]{4}{*}{ Sediment profile } & $\mathrm{df}=2$ & $\mathrm{df}=2$ & $\mathrm{df}=2$ & $\mathrm{df}=2$ \\
\hline & MS $=1.532$ & $M S=8.217$ & $M S=0.422$ & $M S=0.016$ \\
\hline & $F=92.066$ & $F=43.408$ & $F=7.736$ & $F=14.272$ \\
\hline & $p=0.001^{*}$ & $p=0.001^{*}$ & $p=0.022^{*}$ & $p=0.005^{*}$ \\
\hline \multirow[t]{4}{*}{ Station (Sediment profile) } & $d f=6$ & $\mathrm{df}=6$ & $d f=6$ & $d f=6$ \\
\hline & $M S=0.017$ & $M S=0.189$ & $M S=0.055$ & $M S=0.001$ \\
\hline & $F=0.608$ & $F=1.160$ & $F=2.610$ & $F=1.324$ \\
\hline & $p=0.721$ & $p=0.370$ & $p=0.053$ & $p=0.297$ \\
\hline \multirow[t]{4}{*}{ Sampling period (Station-Sediment profile) } & $\mathrm{df}=18$ & $\mathrm{df}=18$ & $\mathrm{df}=18$ & $\mathrm{df}=18$ \\
\hline & $M S=0.027$ & $M S=0.163$ & $M S=0.021$ & $M S=0.001$ \\
\hline & $F=1.417$ & $F=3.489$ & $F=1.141$ & $F=2.794$ \\
\hline & $p=0.162$ & $p=0.001^{*}$ & $p=0.342$ & $p=0.002^{*}$ \\
\hline
\end{tabular}

Summary of results of three-way ANOVA considering species number (S), species abundance (N) and Hill's diversity indices (N1 and N21) for factors sediment profile (effect of different sediment layers-three levels: $0-5 \mathrm{~cm}, 5-10 \mathrm{~cm}$ and $10-20 \mathrm{~cm}$ down through the sediment), station (spatial effect-three levels: station IP-10, IP-17 and IP-38) and sampling period (temporal effect-three levels: prior to trawling period, 30 and 120 days after intense bottom trawling period) (asterisk denotes statistically significant results). 


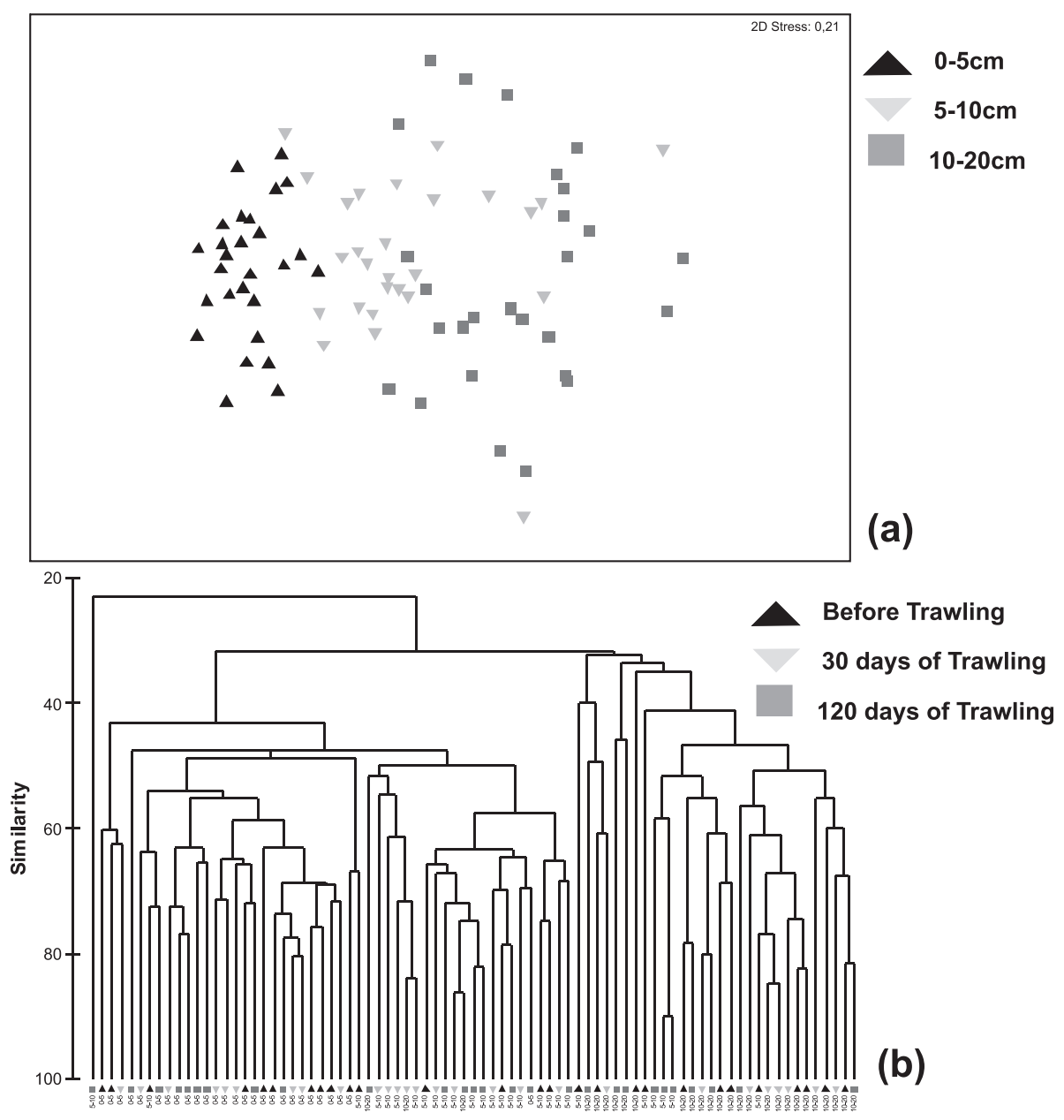

Figure 3 Community structure down through the sediment profiles. (a) MDS ordination plot for the different sediment layers ( $0-5$ ( $\mathbf{\Delta}$ ), 5-10 $(\nabla), 10-20 \mathrm{~cm}(\mathbb{\nabla})$ depth) and (b) Cluster analysis of the different sediment layers before $(\mathbf{\Lambda})$ and after $30 \nabla$ and 120 days $(\mathbb{\nabla})$ the opening of the trawling period.

trophic structure of macrofauna assemblages in Thermaikos Gulf. The latter trophic shift could in return alter biogeochemical processes associated with remineralization of organic material, regeneration of nutrients and nutrient fluxes as well as with benthic-pelagic coupling $[10,36,37]$. In this regard, bottom trawling is likely to induce negative impacts on the functioning of coastal ecosystems [9] and therefore future research on this topic is required.

\section{Vertical distribution of benthic fauna}

Impacts of bottom trawling on the vertical distribution of benthic communities along the sediment are largely unknown despite the fact that trawling gear can penetrate for several centimeters into the sediment thus introducing significant changes to the morphology of the soft bottoms. Results of the present study suggested a steep decline of abundance, species number and diversity indices values

Table 4 Three-way PERMONAVA results of community structure down through the sediment profile

\begin{tabular}{|c|c|c|c|c|c|}
\hline Source of variation & df & SS & MS & Pseudo-F & $p$ \\
\hline Sediment profile & 2 & 43093 & 21547 & 5.1691 & $0.003^{*}$ \\
\hline Station (Sediment profile) & 6 & 25010 & 4168.3 & 1.8651 & $0.002^{*}$ \\
\hline Sampling period (Station - Sediment profile) & 18 & 40229 & 2234.9 & 1.4587 & $0.002^{*}$ \\
\hline Residual & 54 & 82735 & 1532.1 & & \\
\hline Total & 80 & 191067 & & & \\
\hline
\end{tabular}

Summary of results of three-way PERMONAVA of benthic community structure down through the sediment profile with respect to the temporal (three levels: prior to trawling period, 30 and 120 days after intense bottom trawling period) and spatial (three levels: station IP-10, IP-17 and IP-38) variation components (asterisk denotes statistically significant results). 
from the surface down to a depth of $10 \mathrm{~cm}$ within the sediment, which was followed by a milder further decline in deeper sediment layers $(10-20 \mathrm{~cm})$. Community structure patterns also supported the existence of modifications with increasing sediment depth, mainly during the October and February sampling periods. It is known that in muddy bottoms the dissolved oxygen penetrates a few millimeters through a diffusive process into the sediment, whereas it can penetrate down to $10 \mathrm{~cm}$ or even more through macrofaunal burrows, bioturbation activity and irrigation processes $[38,39]$. Among the dominant species inhabiting the deeper layers of the sediment were the suspension feeders Turritella communis, Kurtiella bidentata and Corbula gibba. These species can stand organic enrichment since they construct galleries to accommodate their siphons, which they protract at the surface of the sediment pumping the well oxygenated near-bottom water [35]. Hence, their presence in the deeper layers of the sediment can be considered as typical. However, the increased abundance of the detritus feeding species Tricolia tenuis, of the depositfeeding species Hyala vitrea and Thyasira biplicata, of the parasite species Odostomia unidentata and O. scalaris, and of the carnivorous species Cylichna cylidracea and Bela nebula in the deeper layers of the sediment, suggested the presence of a diverse benthic fauna, which includes many functional groups. The later pattern has been correlated with a deep redox potential discontinuity in the sediment $[38,39]$. It is well known that the passage of the fishing gear induce re-suspension, re-deposition and consequently relayering of the sediment $[3,34]$. So, we assume that bottom trawl passage provokes an increase in which reduced oxygen conditions are met in the sediment (due to re-suspension, re-deposition and consequently re-layering of the sediment). This in return can increase the maximum depth at which certain species could survive. Thus, our results have shown that bottom trawling disturbance could possibly increase the depth of the aerobic layer of the sediment and consequently alter the vertical community structure of benthic species. There is, however, a need for further research on the direct effects of bottom trawling in oxygen profiles of the trawled sediments with respect to benthic communities' vertical distribution, to provide the necessary data to support the generalization of this hypothesis.

\section{Conclusions}

Our findings sustained the notion that bottom trawling, alongside with other types of human induced stressors, can have considerable effects on the structure and function of the benthic domain (Table 5). Therefore, fishery management in Thermaikos Gulf should be redirected from the traditional single species management which is currently active in the area to an ecosystem based fishery management (EBFM) strategy [40] to sustain the health and function of the ecosystem as well as the fishing yields that it supports.

\section{Methods}

\section{Study area and sampling design}

Macrobenthic molluscan communities were examined at three sampling stations (Figure 4) placed across a NW-SW productivity gradient in Thermaikos Gulf, N Aegean Sea [33]. Sampling stations were located across the $50 \mathrm{~m}$ depth isobar since trawling activity is mostly concentrated around that depth. Sampling stations were characterized by silty sediments with mean grain size of 0.012-0.024 mm [33]. The bottom topography of Thermaikos Gulf can be considered as smooth, receiving a significant annual freshwater outflow of $10.2 \times 10^{6} \mathrm{~m}^{3}$ from three major rivers (Aliakmon, Axios and Pinios) [17]. Trawling season, in the study area, opens at the beginning of October and ends in May, while trawl fishing is prohibited during the rest of the year. Sampling was carried out at three periods. The first one took place just before the opening of the trawling season (September 2001 - pre-trawling period, dry calm), while the second and third corresponded to one (October 2001 initiation of trawling, pre-storming low river input period) and four (January 2002 - integrated stormy, high river input and trawling period) months after the initiation of trawling,

Table 5 Summary table of molluscan macrofauna response to environmental variation and bottom trawling activity

\begin{tabular}{|c|c|c|}
\hline Response & Environmental variation & Trawling impact \\
\hline \multirow[t]{2}{*}{ Faunal diversity } & Spatial patchiness & No direct effects \\
\hline & Productivity gradient & \\
\hline Community structure & Latitudinal gradient & No direct effects \\
\hline \multirow[t]{3}{*}{ Functional attributes } & Natural and anthropogenic stressors & Dominance of predators \\
\hline & $\begin{array}{c}\text { Comparable microphytobenthic } \\
\text { biomass }\end{array}$ & Loss of epibenthic herbivores \\
\hline & $\begin{array}{l}\text { Trawling induced sediment } \\
\text { resuspension }\end{array}$ & Loss of filter feeders \\
\hline Faunal structure along sediment profiles & Dissolved oxygen gradient & Alterations in structure \\
\hline $\begin{array}{l}\text { Faunal functionality along sediment } \\
\text { profiles }\end{array}$ & Dissolved oxygen gradient & $\begin{array}{l}\text { Presence of many functional groups deeper in the } \\
\text { sediment }\end{array}$ \\
\hline
\end{tabular}




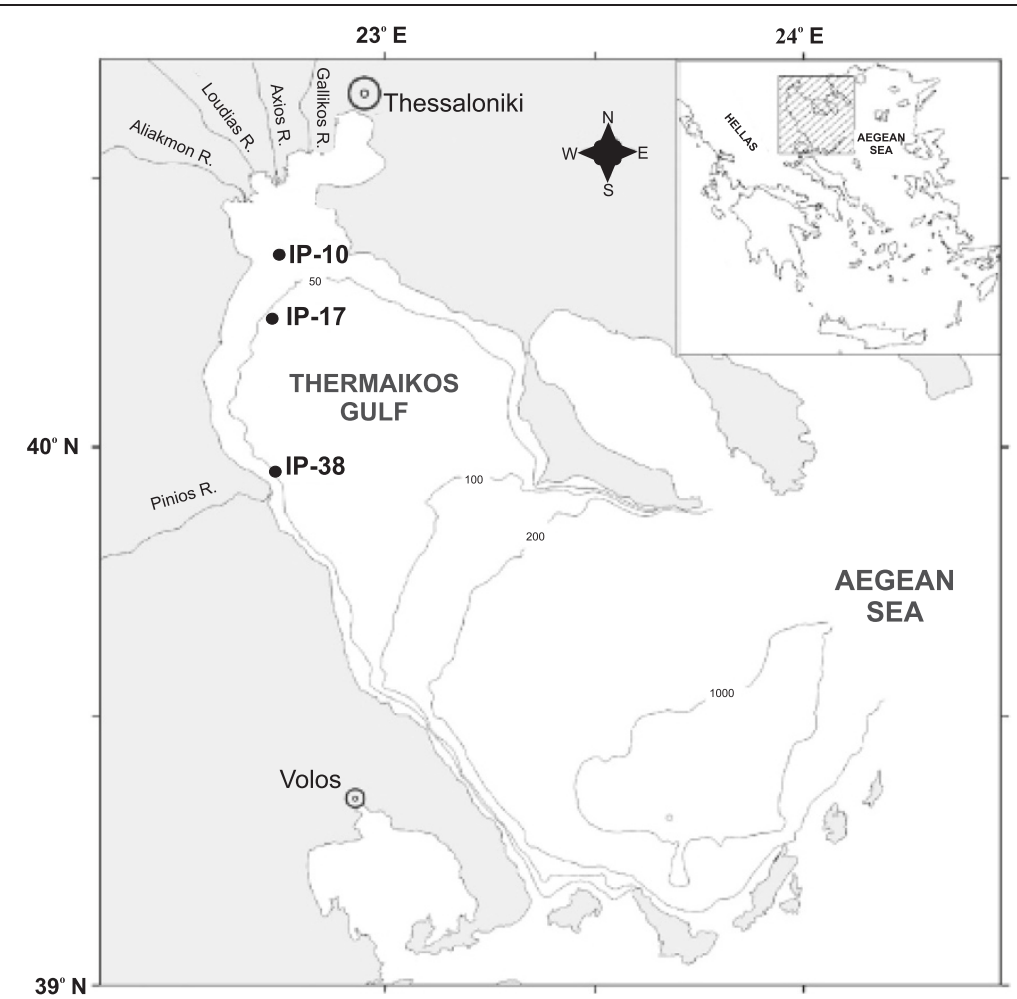

Figure 4 Study area and sampling design (after Pusceddu et al. [33]). Location of sampling stations (IP-10, IP-17, IP-38) across Thermaikos Gulf (N. Aegean Sea, Greece) (after Pusceddu et al. [33]).

respectively. This design was based on the before-after treatment approach to detect possible trawling impacts on molluscan communities [41]. Three replicated samples were collected at each sampling station by means of a $0.25 \mathrm{~m}^{2}$ USNEL boxcorer that is designed for undisturbed samples while it penetrates to a depth of $20-30 \mathrm{~cm}$ into the sediment [see [17] for further details]. Geochemical and physical characteristics of the sampled sediments were described by Pusceddu et al. [33] and Lampadariou et al. [17].

\section{Treatment of samples}

The collected samples were sliced into 3 sections. The first section included the surface sediment $(0-5 \mathrm{~cm}$ depth), the second the layer that follows just below $(5-10 \mathrm{~cm})$ and the remaining the deeper part of the sediment cores $(10-20 \mathrm{~cm})$. All samples were washed through $0.5 \mathrm{~mm}$ sieve, fixed in $10 \%$ formalin and kept separately with the addition of the vital stain Rose Bengal. Macrofauna was sorted into major taxonomic groups and all living Mollusca were identified to species level, counted and weighed.

\section{Data analyses}

Data analyses involved the measurement of several biological descriptors such as species number, species abundance and the following diversity indices: $\mathrm{N}_{1}$ Hill's index and Hill's Evenness N21 (N2/N1) [42]. Classification of molluscs according to their feeding guilds was based on relative literature $([43,44]$ and references therein) and online data bases such as the European Register of Marine Species (ERMS) [45] and the Marine Life Information Network (MARLIN) [46] (Additional file 1). Hierarchical two-way ANOVA was used to detect temporal (i.e. sampling periods, 3-level factor) and spatial (3-level factor, nested in sampling periods) variation of biological descriptors values in the study area. Hierarchical three-way ANOVA was also used to examine the variation of biological descriptors values along the sediment profiles in spatial and temporal scale. The model included the effects of the following factors: sediment profile (3 levels: $0-5 \mathrm{~cm}, 5-10 \mathrm{~cm}$ and $10-20 \mathrm{~cm}$ down through the sediment), sampling station (spatial effect) nested in sediment profile and sampling period (spatial effect) nested in sampling station and sediment profile (temporal effect). Model design was based on the recommendations of Ysebaert \& Herman [47] and references therein. Prior to analysis, data were properly transformed [i.e. $\log (1+\mathrm{x})$ ] when normality and heterogeneity of variance were not met. Significant differences of the allocation of species into feeding guilds between sampling stations and periods were detected with the Mann-Whitney test procedure. Non metric MDS and Cluster analysis were applied for the ordination and 
classification of samples into groups of similar community structure, considering, as well, sediment depth profile. A two-way PERMANOVA [48] was employed to detect significant differences in benthic community structure with respect to the temporal and spatial variation components under the same model design of twoway ANOVA. A three-way PERMANOVA was applied to detect significant differences of community structure along the successive sediment layers in time (temporal effect) and space (spatial effect), under the same model design of three-way ANOVA. Multivariate analyses were based on Bray-Curtis similarity index derived by the transformed (fourth root option) species abundance data.

All calculations were performed with the use of PRIMER v6 software package [49] and SPSS v20 [50].

\section{Additional file}

Additional file 1: Table S1. Molluscan species assignment to their respective feeding guilds. Species list and assignment of each molluscan species to feeding guilds.

\section{Competing interests}

The authors declare that they have no competing interests.

\section{Authors' contributions}

CD participated in the laboratory work, the analysis and interpretation of data, performed the statistical analysis and drafted the manuscript. DK was involved in the laboratory work and data analysis design whereas he also helped to draft the manuscript. ZG carried out the laboratory work, participated in data management and drafted the manuscript. AT was involved in the design of the study, acquisition of data, manuscript preparation and coordination. All authors read and approved the final manuscript.

\section{Acknowledgements}

The authors would like to thank the officers and crew of the R/V's AEGAEO and PHILIA for their assistance during field work. Thanks are also extended to D. Podaras, T. Polychronaki, N. Lampadariou, K. Christodoulou, F. Pantazoglou and P. Polymenakou for helping in all sampling procedures. The study was supported by the Commission of the European Communities (DG-XII) through the INTERPOL project (Impact of Natural and Trawling Events on Resuspension, Dispersion and Fate of Pollutants, Project Number: EVK3-200000023) as well as the Greek Ministry of Development (General Secretariat for Research and Technology). We would also like to thank the anonymous reviewers and the assigned editor for their valuable suggestions that improved the manuscript.

\section{Author details}

'Department of Marine Sciences, Faculty of Environment, University of the Aegean, 81000 Mytilene Lesvos Island, Greece. ${ }^{2}$ Department of Maritime Studies, University of Piraeus, G. Lambraki 21 \& Distomou, 18534 Piraeus, Greece. ${ }^{3}$ National Marine Park of Zakynthos, El. Venizelou 1, 29100 Zakynthos Island, Greece.

Received: 2 July 2013 Accepted: 5 March 2014

Published: 10 June 2014

\section{References}

1. Jennings $S$, Kaiser M: The effects of fishing on marine ecosystems. Adv Mar Biol 1998, 34:201-352.

2. Collie JS, Hall SJ, Kaiser MJ, Poiner IR: A quantitative analysis of fishing impacts on shelf-sea benthos. J Anim Ecol 2000, 69:785-798.
3. De Biasi AM: Impact of experimental trawling on the benthic assemblage along the Tuscany coast (north Tyrrhenian Sea, Italy). ICES J Mar Sci 2004, 61:1260-1266.

4. Hiddink JG, Jennings S, Kaiser MJ: Indicators of the ecological impact of bottom-trawl disturbance on seabed communities. Ecosystems 2006 9:1190-1199.

5. Dayton PK, Thrush SF, Agardy MT, Hofman RJ: Environmental effects of marine fishing. Aquat Conserv 1995, 5:205-232.

6. Lindegarth $M$, Valentinsson D, Hansson M, Ulmestrand M: Effects of trawling disturbances on temporal and spatial structure of benthic soft-sediment assemblages in Gullmarsfjorden, Sweden. ICES J Mar Sci 2000, 57:1369-1376.

7. Kaiser MJ, Clarke KR, Hinz H, Austen MCV, Somerfield PJ, Karakassis I: Global analysis of response and recovery of benthic biota to fishing. Mar Ecol-Prog Ser 2006, 311:1-14.

8. Piet GJ, Rijnsdorp AD, Bergman MJN, Santbrink JW, Craeymeersch J, Bujis J: A quantitative evaluation of the impact of beam trawling on benthic fauna in the southern North Sea. ICES J Mar Sci 2000, 57:1332-1339.

9. Tillin HM, Hiddink JG, Jennings S, Kaiser MJ: Chronic bottom trawling alters the functional composition of benthic invertebrate communities on a sea-basin scale. Mar Ecol-Prog Ser 2006, 318:31-45

10. Olsgard F, Schaanning MT, Widdicombe S, Kendall MA, Austen MC: Effects of bottom trawling on ecosystem functioning. J Exp Mar Biol Ecol 2008, 366:123-133.

11. Kaiser MJ, Spencer BE: The effects of beam-trawl disturbance on infaunal communities in different habitat. J Anim Ecol 1996, 65:348-358.

12. Thrush SF, Hewitt JE, Cummings VJ, Dayton PK, Cryer M, Turner SJ, Funnell GA, Budd RG, Milburn CJ, Wilkinson MR: Disturbance of the marine benthic habitat by commercial fishing: impacts at the scale of the fishery. Ecol Appl 1998, 8:866-879.

13. Hinz H, Prieto V, Kaiser MJ: Trawl disturbance on benthic communities: chronic effects and experimental predictions. Ecol App/ 2009, 19:761-773.

14. Jennings S, Dinmore TA, Duplisea DE, Warr KJ, Lancaster JE: Trawling disturbance can modify benthic production processes. J Anim Ecol 2001, 70:459-475

15. Duplisea DE, Jennings S, Warr KJ, Dinmore TA: A size-based model of the impacts of bottom trawling on benthic community structure. Can J Fish Aquat Sci 2002, 59:1785-1795.

16. Simboura N, Zenetos A, Pancucci-Papadopoulou MA, Thessalou-Legaki M, Papaspyrou S: A baseline study on benthic species distribution in two neighbouring gulfs, with and without access to bottom trawling. Mar Ecol 1998, 19:293-309.

17. Lampadariou N, Hatziyanni E, Tselepides A: Meiofaunal community structure in Thermaikos Gulf: Response to intense trawling pressure. Cont Shelf Res 2005, 25:2554-2569.

18. Azov Y: Seasonal patterns of phytoplankton productivity and abundance in nearshore oligotrophic waters of the Levant Basin (Mediterranean) J Plankton Res 1986, 8:41-53.

19. Ignatiades $L$ : The productive and optical status of the oligotrophic waters of the Southern Aegean Sea (Cretan Sea), Eastern Mediterranean. J Plankton Res 1998, 20:985-995.

20. Coll M, Piroddi C, Steenbeek J, Kaschner K, Ben Rais Lasram F, Aguzzi J Ballesteros E, Bianchi CN, Corbera J, Dailianis T, Danovaro R, Estrada M, Froglia C, Galil BS, Gasol JM, Gertwagen R, Gil J, Guilhaumon F, Kesner-Reyes K, Kitsos MS, Koukouras A, Lampadariou N, Laxamana E, de la Cuadra CM L-F, Lotze HK, Martin D, Mouillot D, Oro D, Raicevich S, Rius-Barile J, et al: The Biodiversity of the Mediterranean Sea: Estimates, Patterns, and Threats. PLoS One 2010, 5:e11842.

21. Colloca F, Cardinale M, Maynou F, Giannoulaki M, Scarcella G, Jenko K, Bellido JM, Fiorentino F: Rebuilding Mediterranean fisheries: a new paradigm for ecological sustainability. Fish Fish 2013, 14:89-109.

22. Sala E, Ballesteros E, Dendrinos P, Di Franco A, Ferretti F, Foley D, Fraschett S, Friedlander A, Garrabou J, Güçüsoy H, Guidetti P, Halpern BS, Hereu B, Karamanlidis AA, Kizilkaya Z, Macpherson E, Mangialajo L, Mariani S, Micheli F, Pais A, Riser K, Rosenberg AA, Sales M, Selkoe KA, Starr R, Tomas F, Zabala $M$ : The structure of Mediterranean rocky reef ecosystems across environmental and human gradients, and conservation implications. PLoS One 2012, 7:e32742.

23. Zervakis V, Karageorgis AP, Kontoyiannis H, Papadopoulos V, Lykousis V: Hydrology, circulation and distribution of particulate matter in Thermaikos Gulf (NW Aegean Sea), during September 2001-October 2001 and February 2002. Cont Shelf Res 2005, 25:2332-2349. 
24. Stergiou Kl, Christou ED, Georgopoulos D, Zenetos A, Souvermezoglou C: The Hellenic seas: physics, chemistry, biology and fisheries. Oceanogr Mar Biol 1997, 35:415-538.

25. Poulos SE, Chronis GT, Collins MB, Lykousis V: Thermaikos Gulf coastal system, NW Aegean Sea: an overview of water/sediment fluxes in relation to air-land-ocean interactions and human activities. J Mar Syst 2000, 25:47-76.

26. Bellan G: Characteristic, indicative and sentinel species from the conception to the utilization. In Terrestrial and Aquatic Ecosystems: Perturbation and Recovery. Edited by Ravera G. New York: Ellis Horwood Lt; 1991:95-100.

27. Borja A, Franco J, Pérez V: A marine biotic index to establish the ecological quality of soft-bottom benthos within European estuarine and coastal environments. Mar Pollut Bull 2000, 40:1100-1114.

28. Hiddink JG, Jennings $S$, Kaiser MJ: Assessing and predicting the relative ecological impacts of disturbance on habitats with different sensitivities. J Appl Ecol 2007, 44:405-413.

29. Ramsay K, Kaiser MJ, Moore PG, Hughes RN: Consumption of fisheries discards by benthic scavengers: utilization of energy subsidies in different marine habitats. J Anim Ecol 1997, 66:884-896.

30. Ramsay K, Kaiser MJ, Hughes RN: Responses of benthic scavengers to fishing disturbance by towed gears in different habitats. J Exp Mar Biol Ecol 1998, 224:73-89.

31. Morello EB, Froglia C, Atkinson RJA, Moore PG: Impacts of hydraulic dredging on a macrobenthic community of the Adriatic Sea, Italy. Can J Fish Aquat Sci 2005, 62:2076-2087.

32. Probet PK: Disturbance, sediment stability, and trophic structure of softbottom communities. J Mar Res 1984, 42:893-921.

33. Pusceddu A, Fiordelmondo C, Polymenakou P, Polychronaki T, Tselepides A, Danovaro R: Effects of bottom trawling on the quantity and biochemical composition of organic matter in coastal marine sediments (Thermaikos Gulf, northwestern Aegean Sea). Cont Shelf Res 2005, 25:2491-2505.

34. Churchill $\mathrm{JH}$ : The effect of commercial trawling on sediment resuspension and transport over the Middle Atlantic Bight continental shelf. Cont Shelf Res 1989, 9:841-864.

35. Arruda EP, Domaneschi O, Amaral ACZ: Mollusc feeding guilds on sandy beaches in São Paulo State, Brazil. Mar Biol 2003, 143:691-701.

36. Graf G: Benthic-pelagic coupling: a benthic view. Oceanogr Mar Biol 1992, 30:149-190.

37. Widdicombe S, Austen MC, Kendall MA, Olsgard F, Schaanning MT, Dashfield SL, Needham HR: Importance of bioturbators for biodiversity maintenance: indirect effects of fishing disturbance. Mar Ecol Prog Ser 2004, 275:1-10.

38. Rosenberg R, Grémare A, Amouroux JM, Nilsson HC: Benthic habitats in the northwest Mediterranean characterized by sedimentary organics, benthic macrofauna and sediment profile images. Estuar Coast Shelf Sci 2003, 57:297-311.

39. Rosenberg R, Nilsson HC, Diaz RJ: Response of benthic fauna and changing sediment redox profiles over a hypoxic gradient. Estuar Coast Shelf Sci 2001, 53:343-350.

40. Pikitch EK, Santora C, Babcock EA, Bakun A, Bonfil R, Conover DO, Dayton P, Doukakis P, Fluharty D, Heneman B, Houde ED, Link J, Livingston PA, Mangel M, McAllister MK, Pope J, Sainsbury KJ: Ecosystem-based fishery management. Science 2004, 305:346-347.

41. Prena J, Schwinghamer P, Rowell TW, Gordon DCJ, Gilkinson KD, Vass WP, McKeown DL: Experimental otter trawling on a sandy bottom ecosystem of the Grand Banks of Newfoundland: analysis of trawl bycatch and effects on epifauna. Mar Ecol Prog Ser 1999, 181:107-124.

42. Heip C, Herman PMJ, Soetaert K: Data Processing, Evaluation, and Analysis. In Introduction to the Study of Meiofauna. Edited by Higgins RP, Thiel H. Washington DC: Smithsonian Institution Press; 1988:197-231.

43. Koulouri P, Dounas C, Arvanitidis C, Koutsoubas D, Eleftheriou A: Molluscan diversity along a Mediterranean soft bottom sublittoral ecotone. Sci Mar 2006, 70:573-583.

44. Dimitriadis C, Koutsoubas D: Community properties of benthic molluscs as indicators of environmental stress induced by organic enrichment. J Nat Hist 2008, 42:559-574.

45. European Register of Marine Species. (ERMS) [http://www.marbef.org/]

46. The Marine Life Information Network (MARLIN). [http://www.marlin.ac.uk]
47. Ysebaert T, Herman PMJ: Spatial and temporal variation in benthic macrofauna and relationships with environmental variables in an estuarine, intertidal soft-sediment environment. Mar Ecol Prog Ser 2002, 244:105-124.

48. Anderson MJ: A new method for non-parametric multivariate analysis of variance. Austral Ecol 2001, 26:32-46.

49. Clarke KR, Gorley RN: PRIMER v6: User manual/tutorial. Plymouth UK: PRIMERE; 2006

50. IBM SPSS: Statistics for Windows, Version 20.0. Armonk, NY: IBM Corp; 2012.

\section{doi:10.1186/2241-5793-21-10}

Cite this article as: Dimitriadis et al.: Benthic molluscan macrofauna structure in heavily trawled sediments (Thermaikos Gulf, North Aegean Sea): spatiotemporal patterns. Journal of Biological Research-Thessaloniki 2014 21:10.

\section{Submit your next manuscript to BioMed Central and take full advantage of:}

- Convenient online submission

- Thorough peer review

- No space constraints or color figure charges

- Immediate publication on acceptance

- Inclusion in PubMed, CAS, Scopus and Google Scholar

- Research which is freely available for redistribution
C Biomed Central 